\title{
From socialist command to a capitalist market economy: the case for an active state
}

\author{
Hubert Gabrisch* \\ Wiesbaden Institute for Law and Economics (WILE), Germany
}

Kazimierz Easki belonged to the group of economists who particularly clearly and convincingly criticized the application of neoliberal doctrines to the transition of socialist countries into market economies. His analysis of the transition agendas was deeply rooted in the Kaleckian tradition of reasoning and brought him much respect but also fierce opposition in the international arena. In answering the why and how of his work, this article will summarize his contributions to the economics and politics of transition.

Keywords: socialism, capitalism, economics of transition, neoliberalism

JEL codes: $P 10, P 20$

\section{INTRODUCTION}

In this article, I summarize Kazimierz Łaski’s contributions to the economics and politics of transition from a centrally planned into a market economy in Central and Eastern Europe (CEE). The period considered includes the years 1989-1997. His contributions consist mainly of policy papers that explain the economic consequences of transition policies by applying the analytical framework of Michał Kalecki. Łaski's dealing with practical transition issues also had an influence on some of his later analytical papers and textbooks, which I will only briefly mention below.

Twenty-one years before the transition started in his home country of Poland in 1989, Łaski, who was of Jewish origin, emigrated, along with many other intellectuals. An influential part of the leadership of the Communist Party, led by the party's first secretary, Wladyslaw Gomułka, triggered an antisemitic campaign that also reached reform-oriented ('revisionist') economists around Michał Kalecki at the Main School of Planning and Statistics in Warsaw (the so-called Kalecki School of Growth ${ }^{1}$ ), and the University of Warsaw, where they taught and jointly researched. ${ }^{2}$ The underlying motive of the campaign was a power struggle in the communist leadership, which Gomulka hoped to solve for himself. Łaski emigrated and settled in Vienna, Austria. In 1989, he held a chair position in economics at Johannes Kepler University in Linz and was a consultant to the Vienna Institute for Comparative [now International] Economic Studies (wiiw), which was

* Email: h.gabrisch@wile-institute.eu. I would like to thank two anonymous referees for useful comments. The article has also benefited from discussions with close friends of K. Łaski. All remaining errors are my own responsibility.

1. For detailed information about the School and Łaski's role, see Osiatyński (1987).

2. For a closer view on the motivations behind the campaign, see Brus (1993: 402-403).

Received 21 December 2018, accepted 25 July 2019 
established in 1973 with the mission of east-west research with practical relevance. ${ }^{3}$ Here, Łaski collaborated with an international staff of young economists and other researchers who had also left Poland and Czechoslovakia. His position allowed him to maintain contact with his former colleagues, such as Tadeusz Kowalik and Jerzy Osiatyński, who stayed in the country, and with younger economists from various academic institutions. Therefore, Łaski remained involved in the debate about the ability of the Soviet-style command economy to reform. His collaboration with Włodzimierz Brus, who had migrated to London, played an important role in dealing with reform issues. With Brus, Łaski intensely discussed and reviewed the idea of market socialism as an alternative to the command economy. They published their critical conclusions in their joint book From Marx to Market in 1989, immediately before the communist rule collapsed in Europe (Brus/Łaski 1989). The book is certainly Łaski's most influential work since his emigration. ${ }^{4}$

However, what followed after 1989 in Poland and then in the other European socialist countries was not a transition to market socialism but rather a transition to a capitalist market economy according to a neoliberal political and economic agenda. Therefore, I will start this article with a historical note on transition in Section 2. Then, I will summarize Łaski's critical position to the concept of market socialism (Section 3) and the neoliberal transition agenda (Section 4). Sections 5 to 8 will focus on Łaski's manner of dealing with selected problems of this agenda: the initial 'shock therapy' in Poland, inflation and fiscal policies, the import shock following the immediate liberalization of trade, and the role of the state during the transition. Section 9 offers my final comments on Łaski's professional legacy and impact from the 'transition decade'.

\section{A HISTORICAL NOTE ON TRANSITION}

Before the transition from socialist command to a market economy started in European countries, China, after Mao's death in 1976, had already been making serious reform attempts since 1978, beginning with agriculture and at first breaking up communes into private lots for better self-sufficiency. A concurrent relaxation of political control encouraged intellectual discussions about the further direction of reforms and two main camps formed: one group intended to learn from reform experiences in developing countries and flirted with neoliberal ideas (Weber 2017). Western economists (among others, Milton Friedman) were invited to present the experiences of Latin American policy reforms. The other camp intended to learn from reform experiences and theories in socialist Europe and invited prominent reform economists. The most famous were Włodzimierz Brus (Poland), Ota Šik (Czechoslovakia) and János Kornai (Hungary), ${ }^{5}$ the first two of whom had left their country after 1968. Both camps seem to have agreed on starting reforms in China with a reform of the price mechanism not only in agriculture but also in industry; however, they disagreed on the meaning and speed of the reform. Šik, for example, with some reference to Oskar Lange's last publication in 1965, believed it would be possible to calculate equilibrium prices in China by using advanced computer techniques. (In hindsight, this belief sounds almost naïve, given the large size of the country and its millions of different commodities and its underdeveloped

3. For an overview on the history, mission, involved persons and activities of the wiiw, see Mayrhofer (2015).

4. A search via Hartzing's Publish or Perish brings up more than 420 citations for this book from a total of about 1400 for all of his publications since the digitalization of publications allowed professional citation-mining using search engines on the Internet sometime in the 1990s.

5. For an overview on their activities, see Weber (2017: 96-144). 
statistical reporting system.) While the 'neoliberal' camp preferred a 'big bang' approach, that is, the one-stroke liberalization of prices and wages, the other fraction preferred a step-by-step introduction of equilibrium prices with further central control and state ownership but the decentralization of investment and production decisions. The big-bang ideas seem to have dominated the reform agenda in the first half of the 1980s. However, attempts at their introduction after 1986 had led to bank runs, hoarding and social unrest and were ended in 1988. The resulting political unrest was suppressed in the Tiananmen Square massacre in June 1989. After that, the Chinese Communist Party, fearing the loss of political and social control, followed a gradual approach, starting with a dual-track price system in agriculture and the partial freeing of prices and wages and followed by the implementation of innovative private and semi-private ownership, including joint ventures with international companies. Nevertheless, most of the industrial and financial sector capital stock is public, as is all of the land; the political monopoly of the Communist Party remained intact, and income and wealth inequality became tremendous.

In contrast, the transition in Europe ended the communist rule and left no room for further market-socialist experiments, such as in the traditionally more reform-oriented Hungary and the socialist 'market economy' in Yugoslavia. European socialist countries experienced a long history of failed market reforms and violent reform suppressions. The Tiananmen Square massacre led to the widespread belief that transition must happen as quickly as possible to deprive the communist rulers of their social and economic power bases. The question of which kind of market economy should be the goal of transition was decided in favour of a capitalist economy. The transition path followed various recommendations that found their blueprint in the 'Washington Consensus', which was the essence of previous policy reform experiences in Latin America in the 1980s and was rooted in the then-dominating economics textbooks that showed strong neoliberal influences. In general, the transition started as a combination of a big bang, or 'shock therapy', and the elimination of communist rule in political and economic institutions - albeit there remained differences between the countries, mostly between Hungary and the others.

\section{3 ŁASKI'S CRITICAL VIEW OF MARKET MECHANISMS IN A SOCIALIST ECONOMY}

The debate on a market mechanism in socialism had made important contributions to global economic thinking between the 1920s and the 1970s. Academically, the possibility of a functioning socialist economy with a market mechanism was proved by Oskar Lange and Abba Lerner in response to Ludwig von Mises' and Friedrich August von Hayek's criticism of socialism in the mid 1930s (the 'socialist calculation debate'). Lange and Lerner attempted to demonstrate that a market mechanism in a socialist economy is possible and can reconcile efficiency with full employment, applying the neoclassical model of Walras and replacing the auctioneer with the central planning authority. The latter would calculate equilibrium prices for a full-employment situation and fix them for autonomous socialist enterprises, which would respond with quantity adjustment: just like in the neoclassical model, firms would act as price-takers in conditions of perfect competition. Many economists in the socialist world took up this idea and influenced numerous reform attempts, mostly combined with a certain degree of workers' self-management, after Stalin's death in 1953.

Łaski had some sympathy for the idea of market mechanisms, not least because he had collaborated closely with Brus since 1949. For example, they jointly presented a paper in 1965 at a symposium in Warsaw honouring Oskar Lange in which they provided an 
overview about the debate on the 'law of value' - the term used for market mechanisms at that point - and argued that the law can be activated by means of socialist planning when some conditions are fulfilled (Brus/Łaski 1965). At this time and equipped with a professorship at the Higher School of Planning and Statistics (SGPiS) in Warsaw, he also collaborated closely with Kalecki. But Kalecki was sceptical to the idea of a market mechanism related to expanded competences of worker-managed enterprises. He had argued that the participation of workers in the profits of enterprises may lead to unemployment, in much the same way that profit maximization in capitalist enterprises leads to unemployment (Kalecki 1956). According to Kalecki's profits theory, the price system can merely distribute the amount of profits between the capital owners but is far from fulfilling the neoclassical assumption of equilibrating supply of and demand for labour on the macro level. Full employment through investment is the task of central planning in a socialist economy, and of an activist government in a capitalist economy. This conclusion is the red thread throughout Łaski's research and writing, including his later contributions to the transition literature.

After his emigration, Łaski became more sceptical about the foundations of the idea of a socialist market economy in theory and in the real world. Indeed, all experiments to implant a market mechanism into the command economy had failed, not least because the fundamental problem of transforming labour values into money prices was not solved, as Brus (1993) later admitted. ${ }^{6}$ Therefore, the reform attempts did not deliver their basic material promises. Rather, they seem to have produced chaos, consumer goods shortages, and social and political unrest, and delivered the case for the ruling communist elite to suppress the opposition and, with it, their reform movements. This happened in Poland in December 1980 (martial law) and with Soviet President Gorbachev's chaotic reforms at the end of the 1980s (failed military coup in August 1991). Brus qualified these experiences in sum as the 'bane of reforming the socialist economic system' (Brus 1993: 364).

After all of these depressing experiences with reforms of the command economy, Łaski and Brus summarized their distance from the socialist market concept in their 1989 book From Marx to Market. In the preface to the German edition, which was published one year after the English edition, they concluded that market socialism would show almost no advantages compared to a private market economy, but would show many disadvantages (Brus/Łaski 1990: 10). In a joint publication with Amit Bhaduri in 1997, Łaski underlined the following:

Almost every observer agrees that privatization of the most important sectors of the economy, especially industry, is a necessary precondition for an efficient market system. (Bhaduri/Łaski 1997: 117)

And in an interview in 2007, he stated the following:

Economies involve risk, and risk cannot be tackled if you have no private ownership. ... It is a point that we have often neglected in debate ... . De facto, Oskar Lange has won the debate about market socialism, but that debate was not centred on the real economy; instead, it assumed a general equilibrium and works in a situation of general equilibrium, because the information is there and everything can be calculated. Basically, skilfully programmed computers could do it. However, the problem of risk would be beyond even the most skilfully programmed computers,

6. More precisely, the law of value postulates that the money price relations of commodities reflect the relations of human labour that are socially necessary for their production. To make the law functional in a socialist economy, one needs to transform the labour values into money prices. But the 'transformation problem' is widely assessed to be an unsolved problem of the Marxian labour theory of value. 
because they cannot actually take everything into account. I actually think that Lange's victory was a Pyrrhic victory and that Hayek came closer to the truth. (Laski 2012: 130-131)

Conceding that Hayek was 'closer to the truth' than Lange did not mean that Łaski would take over the former's hostility towards any form of an active state. Łaski believed that the realization of the socialist ideals of full employment, just incomes, wealth distribution and equal chances for everybody would be possible in a market economy with mixed, albeit prevailingly private, ownership and an economically active state. Łaski saw his credo justified by his life experience in Austria, his new homeland. There, one and a half years after he had left Poland, the social democrat Bruno Kreisky took over the government and perfected the social partnership model to achieve and ensure the goals mentioned above. Łaski substantiated his views in his book Gospodarka kapitalistyczna bez bezrobocia (A Capitalist Economy Without Unemployment), published just a few months before his passing (Łaski 2015).

\section{THE REJECTION OF THE NEOLIBERAL TRANSITION AGENDA}

Łaski observed with bitterness that many former reform economists in socialist countries as a response to the failure of the idea of a socialist market economy - had

made a full turnabout and moved from Marx and Keynes-Kalecki directly to Mises and Hayek. They did not only accept the latter's criticism of orthodox socialism, which after all had been correct, but took over their extreme liberal position identifying any economic action of the state with socialism. (Łaski 1992a: 52).

When he mentioned 'extreme liberal positions' in connection with Hayek, Łaski meant what we today call 'neoliberalism'. It is the offspring of various theories, but mainly of two. First, it is akin to the Austrian school of economics, which is characterized by methodological individualism and the rejection of any kind of collective action, including an economically active role of the state. It is typical for methodological individualism to derive economic behaviour from unchangeable parameters of human nature and to critique any social restriction to this natural behaviour as collectivism. Hayek's critique of socialism went far beyond the socialist calculation debate. He accused Keynesianism of going in a similar direction. The second main source of neoliberalism is German ordoliberalism after Walter Eucken, which added the idea of a rule-based liberal order. The state should be scaled downward to a mere rule-maker and should abstain from interventions into the market processes; and all its activities should be subordinated to clear rules. Therefore, a balanced fiscal budget must be achieved not by higher taxes but by cutting back expenditures. The idea of a rule-based liberal order was a blueprint for the transition agenda and also prevails in modern economic policy-making.

The first practical programme was implemented in Germany in 1949 through the famous Erhard reforms, which eliminated price and wage restrictions and the extant relics of the former Nazi command economy. The reforms are widely assessed as a success story, although they initially produced high unemployment ${ }^{7}$ and later served as a role model for many other countries, including socialist countries after 1989. Further neoliberal reforms were executed in Chile after the military coup in 1973. The script for Chile was written by economists at the Chicago School of Economics, which was the centre for neoliberal

7. The unemployment rate increased from 3.2 per cent to 8.7 per cent between June 1948 and June 1949 . 
economics in the US university landscape (Friedman and Hayek taught there). In Chile, the term 'shock treatment', seemingly coined by Friedman, became a public synonym for neoliberal reforms. Hayek's hostility towards state interventionism excluded neoliberalism from mainstream economics until the late 1970s. It gained dominance after Hayek and Friedman were awarded Nobel Memorial Prizes in 1974 and 1976 respectively. The ascent of neoliberalism was the result of the crises in Latin American countries in the 1980s and the collapse of the socialist system in Europe. In Latin America, a few countries suffered from hyperinflation, were unable to service external debt, and underwent harsh austerity programmes, resulting in that time frame being known as the lost decade. In Bolivia, Jeffrey Sachs, who later became a leading advisor to the transition agendas of Poland and Russia, contributed in 1985 to a programme of cutting price controls and government activities. The policy reforms in Latin America were later summarized under the label the 'Washington Consensus' and became a guide for the transition to a market economy in formerly Soviet-ruled countries.

In particular, the Erhard reforms were suggested as a blueprint for transitions to a market economy, for example by Milton Friedman in the case of China (Weber 2017: 100-102) and by German ordoliberals in the case of some European countries. In a comment on a workshop paper in 1990 that advocated the general validity of the ordoliberal approach with its alleged German success, Łaski decidedly rejected the argument as being a post hoc fallacy:

We cannot prove generally, and in social sciences particularly any theory. ... [W] e can say that social experience has rejected the viability and rationality hypothesis of a socialist system. ... In the same sense, we can also say that the history of the FRG [Federal Republic of Germany] did not disprove the neoliberal concepts of von Eucken. ... If post hoc could be interpreted as propter hoc, then a lot of other theories and concepts would have been 'proven' by recent history. (Łaski 1992b: 96)

This brief passage reveals the fundamentals of Łaski's way of practical thinking. While neoliberalism attempts to find universal economic 'laws' by abstraction from the real social world and deduction by axiomatic logic, Łaski, in the tradition of the leaders of the Keynesian revolution, has seen economic laws be conditional based on social arrangements. Society is a fabric of human relationships. Then, a theoretical statement can be derived by contextual logic, and the same economic policy can produce very different results for different initial conditions. Łaski's 'post hoc argument' above reflects such initial conditions by pointing out that under Nazi rule, Germany was even a 'monetized ... economy dominated by private property relations' (ibid.). One can add that the success of the 'Erhard reforms' also benefited greatly from their 'context', namely the rising global demand triggered by the Korean war between 1950 and 1953. A demand push of a similar size could not be expected for the CEE countries in 1989.

\section{THE CLASH OVER 'SHOCK THERAPY' IN POLAND}

When the new Polish government came into office in September 1989, a group of Polish and foreign advisors provided support for a transition agenda prepared by Leszek Balcerowicz. Balcerowicz, a former market-socialist reformer, had spent a study visit in 1988 in Marburg, a centre of ordoliberalism in Germany. The group around him included, among others, Jeffrey Sachs, Stanisław Gomułka and Jan-Vincent ('Jacek') Rostowski. Sachs was a trained macroeconomist and a full professor of economics with tenure at Harvard. Gomułka was a reader in economics at the London School of Economics (LSE), 
the neoliberal centre in Great Britain's university landscape (Hayek taught there from 1931 to 1950). Rostowski held a Master's of Science in Economics from the LSE and was a lecturer there. All three were decided proponents of shock therapy. Their influence was strong enough to promote Balcerowicz to the office of Finance Minister instead of the more étatistic Witold Trzeciakowski. Łaski became their main opponent.

Following the neoliberal agenda, the Balcerowicz plan included the immediate freeing of almost all prices, nominal wage controls, a drastic rise of nominal interest rates, a harsh devaluation of the currency, and the transformation of the budget deficit into a surplus. The plan aimed to prevent the hyperinflation that was feared after price liberalization and a quick recovery of the economy after 'getting the prices right', which meant achieving prices that equilibrated demand with supply at the micro and macro levels. The officials responsible for the plan expected a decline in GDP of approximately 3 per cent for 1990, and the recovery would start after a few months of decline.

When the Balcerowicz Plan was formulated after 24 August 1989, Łaski had been in Warsaw several times. He served as an official advisor to the new minister, Jerzy Osiatyński, who became the head of the Central Planning Office (CPO) and was a close friend to Łaski. The CPO staff provided Łaski with statistical data and other necessary information. Łaski applied the Keynes-Kalecki analytical methodology in a simplified form, which seemed adequate for a country with a parsimonious database (no national accounting according to the UN standards). The disastrous results he obtained for the shock therapy and, probably even more so, for the methodology he applied for his estimation provoked a major clash between him and the apologists of the neoliberal agenda.

Łaski's approach was as follows: ${ }^{8}$ The gross domestic product or GDP $(Y)$ is distributed among private households, mostly as wages $W$ and profits $R$, both before taxation: $Y=W+R$. This income is spent through private consumption $C$, gross investment $I$, government current expenditures for goods and services $G$, and net foreign consumption $E$ (the trade balance): hence, $Y=C+I+G+E$. Gross investment includes private and state investment. It is important to note that state investment comprises the bulk of business investment in a socialist command economy. Since government current expenditure includes subsidies to state enterprises, efforts to balance the government budget always means a subsequent reduction in the state enterprises' investments. After equating the two approaches to GDP, subtracting taxes on both sides (including social security payments and net government transfers) $T$ and consumption $C$, one obtains:

$$
(W+R-T)-C=I+(G-T)+E .
$$

$(G-T)$ denotes budget deficit $D$. $(W+R-T-C)$ is savings $S$ of private households and enterprises after taxation, and we receive the well-known form of

$$
S=I+D+E \text {. }
$$

Formally, equation (2) appears to be an identity, but in Kalecki's theory of effective demand, it reflects a causality running from investment (plus government deficit and external demands) to domestic savings but not vice versa: Capitalists cannot decide on their profits, but only on their investments. Investments in turn determine profits, as has been shown in Kalecki's famous profits equation.

8. The detailed method of calculation and the data used were published by Łaski (1990) in the Polish language, and in a shorter version in the English language (Łaski 1992a: 40-45). The English version differs from the original Polish version in variable notation for savings $S$. 
Because the saving ratio $s=S / Y$, one receives

$$
Y=\frac{1}{s} S
$$

where $1 / s$ is the multiplier. If neither $s$ nor $S$ are constant, one obtains

$$
1+g Y=\frac{1+g S}{1+g s},
$$

where $g$ denotes the operator for the rate of change in the variables. After rearranging, the equation changes into

$$
g Y=\frac{\Delta Y}{Y}=\frac{g S-g s}{1+g s} .
$$

Equation (5) should be used when changes are large. In the case of small changes of $s$, the equation can be approximated by

$$
g Y=g S-g s .
$$

Łaski inserted the target figures of the Balcerowicz Plan for investment, the trade balance and the state budget as components of savings via equation (2) into equation (5), and obtained a 29 per cent fall of GDP as the result. He furthermore made the simplifying assumption of a constant saving ratio $(g s=0)$ for the short period because he conceded that 'at the beginning of 1990 nobody knew for sure how the rate of savings would change' (Easki 1992a: 44).?

When he presented his estimations to the Polish government in early 1990, he was met with arrogance and rejection by the advocates of the Balcerowicz Plan. He was accused of 'blatant methodological errors' in his analysis, mainly around his assumptions of a constant saving ratio; other remarks were simply insulting. Łaski retorted with a detailed justification of his methodological approach, showing that the criticisms had missed the point. ${ }^{10}$ He found support from former collaborators whom he and Kalecki had worked with, such as Tadeusz Kowalik, Wiktor Herer and Władysław Sadowski - all of whom were victims of the 1968 purges.

The actual economic results were quite unexpected for the authors of the plan and disastrous for millions of Polish households as well as for state-owned and newly established small-scale private enterprises: the GDP declined by 12 per cent in 1990 (four times the planned goal); inflation was far higher than anticipated due to the strong devaluation of the Złoty, and thus, with nominal wage controls, real wages decreased by 28 per cent, contributing to a contraction in private consumption of 24 per cent. The cut in subsidies and the shock-like increase of the interest rates provoked a fall in total investments of 15 per cent. The feedback effects and delayed responses of households and state enterprises to the Balcerowicz Plan let the GDP fall by another 12 per cent in 1991, so that the cumulated decline of both years was approximately 25 per cent compared to 1989 , and, hence, quite close to Laski's estimate.

The shock therapy was applied in most other transition countries and showed similar effects. Hungary was an exception, because it followed a more gradual process without any

9. He made a second calculation using equation (6) and assumed a redistribution from wages to profits of the enterprises and obtained a fall in GDP of 34 per cent.

10. See the exchange of notes between Rostowski and Łaski via Minister Osiatyński in a collection of 1990 documents edited by Gomulka/Kowalik (2011); notably, see footnote 1 on p. 155! 
comparable GDP decline (Kornai 1997). The advocates of the neoliberal transition agenda tried to explain the unexpected decline in Poland with supply shocks, using the textbook aggregate supply/demand AS-AD model (Gomułka 1991). Among the alleged supply shocks, they identified the 'unexpected' breakdown of intra-Soviet-bloc trade and strong, industry-specific shocks after price liberalization. Some years later, many studies that were based on better data and performed with econometric methods - among them an IMF survey on the region (IMF 1993: 142) - confirmed Łaski's findings, namely that macroeconomic policies explain the losses in GDP and employment but not the industry-specific shocks. Łaski's assessment of the Balcerowicz Plan substantiated his belief that demand management by the government is necessary to mitigate policy shocks on output and income.

The ignorance Łaski met with when he presented his estimation to the government in Warsaw was probably one of the motivations behind his acceptance of the offer to become the director of the internationally renowned wiiw. In that position (from 1991 until 1996), he had the resources to gather international economists with a similar distance to the neoliberal transition agenda. His cooperation with Amit Bhaduri, a consistent critic of neoclassical theory, played a specific role. Bhaduri had become interested in transition issues, visited Vienna often, and contributed several studies that were mostly published by the Vienna Institute. Łaski and Bhaduri devoted a large part of their joint research on theoretical issues in Vienna and later, in 1994-1995, as fellows of the Institute for Advanced Studies (Wissenschaftskolleg) in Berlin. There, they wrote - jointly with Martin Riese - a critical study on the AS-AD model that played a major role in the defence of the Balcerowicz Plan. Their theoretical study reveals that the assumption of a demand and supply curve, independent of each other, must lead to two incompatible employment levels at the same price level, and thus the assumption lacks consistency. This makes the use of the price mechanism in stabilizing the economy impossible (Bhaduri et al. 2003) - as practically proven in Poland and the other transition countries.

\section{GOVERNMENT FINANCE AND THE CHARACTER OF INFLATION DURING TRANSITION}

Almost all former socialist countries were highly indebted in convertible currency due to the foreign credit financing of imports in the 1970s and 1980s. A government could achieve private and official debt restructuring agreements with the London and the Paris Club only after achieving stand-by agreements with the IMF on the basis of a letter of intent in which the government described its reform and adjustment programme - negotiated with the Fund - that was actually in line with the Washington Consensus. A cornerstone of the consensus was fiscal discipline because textbook economics assumed that budget deficits and overindebtedness were sources of hyperinflation (a monthly inflation rate of more than 50 per cent for more than three months). Thus, part and parcel of the consensus were fiscal discipline on the expenditure side and reforms to lower the marginal rates of taxation and to broaden the tax basis.

After his appointment as director of the wiiw, Łaski turned in his research towards government finance. At first, he published the results as a research report of the Vienna Institute in 1993 (Easki 1993) and later in the 1995 edition of the German Economic Association (Verein für Socialpolitik). Łaski started with some observations in the early transition period; he observed that the balanced budget during the transition period was only short-lived due to the extraordinary revenues from currency devaluations, but it reappeared soon and has persisted since then. His analysis of revenue statistics clarified 
the reasons behind this (Easki 1995): the tax basis collapsed due to the GDP decline of approximately 25 per cent and the simultaneous disappearance of tax revenues from profits and due to tax evasion and tax exemptions for private and foreign firms; the expected budget revenues from privatization did not materialize either. According to Łaski, the remedy of neoliberal policy, namely a further cut of budget expenditures following declining tax revenues, would prolong the output crisis and further narrow the tax basis. He included a tax revenue function in the model outlined in Section 5 above (equation (1)) and showed that maintaining a balanced budget when tax revenues decline will, contrary to what was assumed in the fiscal plans, induce profits $R$ and then savings $S$ to fall. Additionally, it was clear to him that a further expenditure-induced fall in aggregate demand would not only hit the 'hostile' state enterprise sector but also cause the environment for new private firms to deteriorate.

Again, Łaski was in fundamental disagreement with the neoliberal agenda, which believed in the inflationary pressure of government expenditures and thus required 'sound' fiscal policies in all circumstances. Łaski was not too concerned about the threat of hyperinflation in most transitional economies. A hyperinflationary situation occurs 'when the sum of the budget deficit, private investment and the trade balance, hence, total demand, hits the capacity limits of the economy' (Easki 2015: 126). ${ }^{11}$ Only then would an exploding budget deficit financed by the central bank trigger a process in which the velocity of money circulation reaches its maximum and the dynamics of inflation converge with the growth rate of the money supply. Łaski assessed the transition countries as being far from such a situation. The money overhang inherited from the command economy was eliminated through a 'corrective' inflation after price liberalization. Due to the transition shocks, the economy would work far below its capacity. The economy would function like a 'standard' market economy, supported only initially by nominal exchange rate and wage anchors to control inflation (Bhaduri/Łaski 1997).

Łaski was more worried about the real economy costs of fighting 'normal' inflation with credit constraints, high real interest rates and fiscal retrenchments. To explain normal inflation, he reverted to the different characters of cost- and demand-determined prices (Łaski 1992c) - another of Kalecki's major contributions to economics (Kalecki 1971). Cost-determined prices prevail in manufacturing, as do demand prices in agriculture and resource industries. When an industrial firm notes a change in demand for its products, it will not react with price adjustment but with quantity adjustment. Hence, 'normal' inflation in an industrialized market economy is basically a cost-push inflation, and so it is in most transition countries with their achieved industrial level. A demandpull inflation with the possible threat of turning into hyperinflation appears in supplyconstrained economies, hence in agricultural or resource economies, such as in many Latin American countries. Here, a change in aggregate demand might lead to a price adjustment even when capacity is under-utilized. Łaski concluded that

experiences of hyperinflation [in Latin America] cannot be simply transmitted to other conditions, including that of a normal inflation, especially cost-push inflation. (Łaski 1995: 69)

Ongoing credit restrictions, budget surpluses and high real interest rates with the aim of fighting any inflation would reduce effective demand far beyond what is necessary and would impoverish the population and thus undermine support for reforms. To avoid persistent cost-push inflation, Łaski recommended the control of cost factors through income policies, including tri-partite agreements, plus avoiding excess nominal devaluations (the import of inflation).

11. My translation from Polish. 


\section{THE IMPORT SHOCK}

Overnight, East Germany had become, through unification with the Federal Republic of Germany, a member of the European Union (EU) and its free trade system. The East German transition was de jure and de facto an import of the complete institutional system of West Germany, including its integration into global and EU markets; thus, the external opening was even more radical than in the other transition countries. For example, devaluations of an own currency were inapplicable. There, as well as in the other transition countries, a downward quantitative adjustment - similar in dimension occurred under the pressure of foreign competition.

During his research stay at the Wissenschaftskolleg in Berlin, Łaski became interested in the impact which trade liberalization was having on income and employment. Łaski's starting point was, as usual, an observation: The trade shock in transition countries appeared mainly as an import shock. Private households, as well as private firms and state enterprises, used their available income, which was now convertible into foreign currency, for the purchase of newly accessible and superior foreign consumer and investment goods, even when their prices were higher. The traditional exports of command economies, namely raw materials and intermediate goods, remained roughly unchanged because they were competitive. Łaski published his analysis and conclusions in the study 'Macroeconomic problems of trade liberalization and EU eastern enlargement' in 1997 (Łaski 1997).

Łaski modelled the effects of the import shock on domestic output using the same approach as before with respect to the Balcerowicz Plan. He specified net exports $E$ in equation (2) above by the import function $M=M_{a}+m Y$, where $m$ is the economy's average propensity to import, dependent on income $Y$, and $M_{a}$ denotes those imports independently of GDP. The savings function in equation (2) is augmented by the trade balance identity as

$$
S=I+D+E=I+D+X-M_{a}-m Y,
$$

with $X$ denoting exports. Compared to imports, which are determined by domestic demand and non-demand factors, exports are determined by external factors. Holding exports $X$ constant, net exports $E$ fall when $Y$ and/or autonomous imports $M_{a}$ are increasing. Łaski observed the trade shock as an increase in the latter. In fact, it would have been incorrect to describe the import shock by a higher import propensity $m$. According to Engel's law, with decreasing real income following the price shocks, the proportion of income spent on qualitatively inferior - domestically produced - goods should have risen and $m$ should have declined. However, after the shock-like trade liberalization, imports increased despite a falling real income. The massive imports were the result of psychological factors rather than changes in income. Demand for superior Western commodities, ${ }^{12}$ especially food, increased with falling real income. Therefore, the trade balance equation should include a change in autonomous imports and equation (7) changes into

$$
I+D+E^{\prime}=I+D+X-M_{a}-\Delta \boldsymbol{M}_{a}-m Y .
$$

And the augmented equation (3) changes into

$$
Y=\frac{1}{s+m}\left(I+D+X-M_{a}\right) .
$$

12. The popular phrase in East Germany was 'test the West'. 
As in the Kaleckian framework, investment $I$ is determined by decisions in previous periods, exports $X$ by external factors, and $D$ by political decisions; they are also independent of current $Y$ and are hence held constant for the following formal analysis. ${ }^{13}$ Then, the import shock affects the GDP according to

$$
\Delta Y=-\frac{1}{s+m} \Delta M_{a} .
$$

A one-unit import shock results in a fall in GDP of more than one unit because $0<(s+m)<1 .{ }^{14}$ According to equation (3), savings are an increasing function of $Y$. However, the $E$ and $E^{\prime}$ parts in equations (7) and (8) are decreasing functions of $Y$ due to the negative impact of income-determined imports $m Y$ on net exports $E$ when $I$ and $X$ are constant. The effects of the import shock are illustrated in Figure 1.

The horizontal axis in Figure 1 depicts the GDP $Y$, and the vertical axis savings $S$. According to equation (3), savings are increasing in $Y$, and according to equations (7) and (8) decreasing, because $E$ and $E^{\prime}$ are falling due to $X-m Y$. The position of the curves of equation (7) and (8) is determined by $I$ and $D$, which remain unchanged when $Y$ changes with imports. The upper $(I+D+E)$ function captures the situation before trade liberalization, the lower $\left(I+D+E^{\prime}\right)$ function after the trade liberalization shock, because $E^{\prime}=E-\Delta M_{a}$.

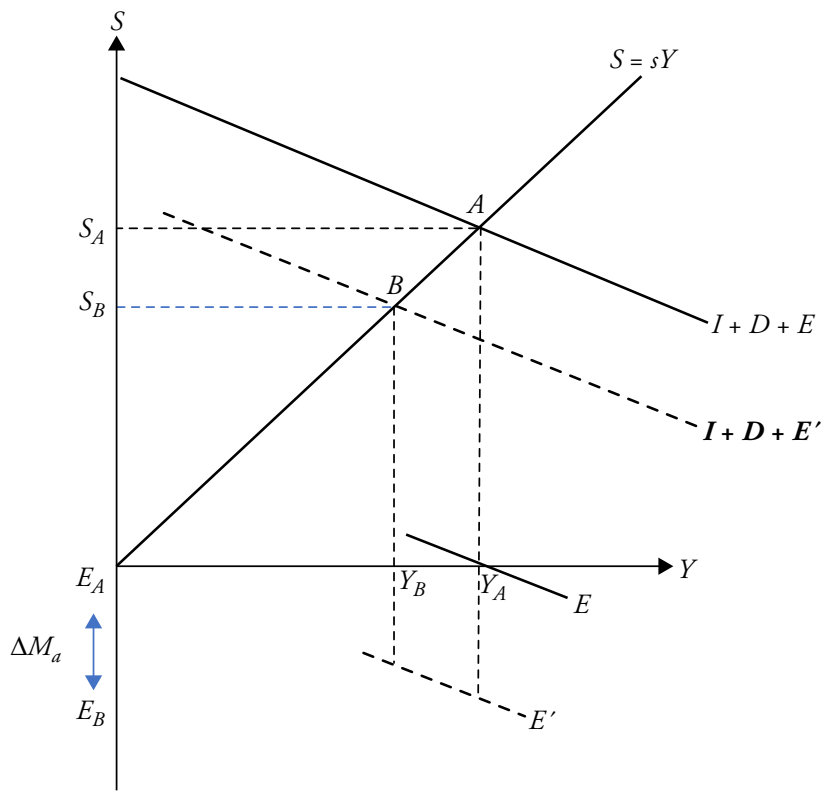

Source: Author's rendering after Łaski (1997).

Figure 1 The effect of the import shock on GDP

13. This does not completely hold for $D$, because taxes are income-sensitive; for the sake of simplicity, Łaski assumes a lump-sum tax.

14. When larger than 1, income is exclusively saved and spent on imports - a rather implausible case. 
With given investment and budget deficit, and under the assumption that the trade surplus initially equals zero, the negatively sloped $E$-function cuts the horizontal axis in $E_{A}=0$ in the starting situation in $A$, with $\left(I_{A}+D_{A}\right)=S_{A}$. The sum of investment and domestic private and public consumption or absorption is equal to GDP; in other words, GDP finds its domestic market. The import shock shifts the $E$-function by $\Delta M_{a}$ towards $E^{\prime}$ and $E_{B}$ becomes negative. The multiplier ensures that domestic production shrinks, and this, in turn, will also reduce the income-dependent imports $m Y$ (but not autonomous imports). With unchanged investment and government deficit, a new intersection between $S(Y)$ and $\left(I+D+E^{\prime}\right)$ is reached in point $B$. Here, domestic absorption is larger than domestic output. The negative trade shock could be mitigated by various policy measures, of which Łaski noted the following with respect to the transition countries: (i) a devaluation of the real exchange rate; (ii) the expansion of domestic investment and/or the budget deficit; and (iii) import protection. Options (i) and (iii) would suppress $m$. Option (ii) would shift the investment or budget function upwards.

A sharp devaluation accompanied trade opening in most transition countries except East Germany. Łaski argued that a devaluation would reduce $m$ and rotate the $\left(I+D+E^{\prime}\right)$ function upwards. However, he was convinced that this effect would be of minor relevance because the devaluation would be followed by a higher inflation rate, compensating for the real depreciation and thus buffering the effect of $\Delta M_{a}$ only temporarily. Here, he was right because the harsh devaluations of the exchange rates of the Polish Złoty and the Czechoslovak Coruna at the beginning of the transition only extended the period of corrective inflation after price liberalization. In contrast, the specifics of the East German transition included a double trade shock by the trade opening shock plus a real appreciation when the Deutsche mark was introduced in the German Democratic Republic (GDR), which meant an increase in $m$. As a consequence of this appreciation, East German exports also broke down massively, so that the $(I+D+E)$ line simultaneously shifted and rotated downwards.

The second option would be shifting the investment function $I_{A}$ upwards. This, however, would have required external assistance by foreign credits or direct investment into the domestic capital stock. Łaski was realistic because he knew that the foreign-exchange reserves of the former command economies were not strong enough for a huge credit and investment programme. Even in the case of East Germany, with its broad and strong access to international capital markets via West Germany, the inflow of foreign investment into new capacities was not strong enough to mitigate the double trade shock.

A rightward shift of the function could also be reached through higher deficit spending by the government, hence through higher government expenditure. In most transition countries, this option was ideologically not acceptable within the neoliberal concept. However, it became the strategy for East Germany, forced by some foreseeable detriments of the unification with the West German economy and society (for example, mass migration). Deficits in the German federal budget and in the budgets of the newly established East German Länder, financed by federal transfers and transfers from the West German Länder, in combination with a massive government investment programme, should have helped to create a competitive export basis and income in the related sectors at the same time. However, the higher deficits and large investment transfers were not sufficient to compensate for the combined massive import and real appreciation shocks.

Łaski was convinced that there remained a strong case for imposing either a differentiated tariff structure or other differentiated protection measures (option (iii)). He held much sympathy for the Southeast Asian countries which practised an active industrial policy, imposed preferential taxes, subsidized credits and arranged links between the 
government and the business sector. He pointed to the fact that each country had applied protectionist measures in certain periods of its own history and was mostly successful in developing its industrial system and wealth; the most recent examples in Europe were Germany and Austria in the 1950s and 1960s and, even more recently, China, which adopted a combination of all of these measures of government intervention. Indeed, this was the most realistic option. The so-called European Treaties with the European Community, of which the first came into force in February 1994 between Poland and Hungary, brought an asymmetric cut in tariffs in trade for manufactured goods; while the European Communities (later the EU) lifted all tariffs on imports from transition countries, the latter could raise import duties for a transition period (actually until their accession to the EU in May 2004).

\section{THE ROLE OF THE STATE DURING THE TRANSITION}

Łaski's understanding of the role of the state completely contrasts with the neoliberal idea of the state as a mere rule-maker that should not intervene in the spontaneous order of markets. He did not believe in the self-adjustment process of markets. In his 1997 paper jointly published with Amit Bhaduri (Bhaduri/Laski 1997: 116-117), he wrote:

The dominant role of the authoritarian state in the command economy together with the formal suppression of private initiative killed the private and even collective creativity which has always been the driving force behind economic progress. This was the definitive reason for the ossification of this system long before it collapsed. Hence, it was understandable that the transformation from the command to a market economy was accompanied by an overriding tendency to push back the state and to rely in economic matters almost exclusively on the spontaneity of market forces. The fashionable doctrine of a minimal state naturally looked attractive in this context. It was, however, a false start.

Consequently, Łaski rejected the attitude of the first new governments in leaving the state enterprise sector - suddenly deprived from subsidies and credit and exposed to predominant foreign competition - completely to its own devices. Łaski was convinced this would lead to fraud and corruption and finally to the plundering of public assets for private gains by uncontrolled state managers. He was right: asset stripping became widespread in all transition countries and led to the rise of oligarchs, mainly in the main successor states of the Soviet Union.

He shared the view that the state creates external economies, which the private sector can internalize to increase its revenues and profitability. This principle also applies during transitions because creating external economies is a key component of the progress of the private sector in an economy with omnipresent state enterprises. External economies substantiated his attitude against a quick privatization of state assets, mainly in capital-intensive industries. Łaski was sceptical of concepts of quick privatization because he knew that there were only small savings in the population and little professional expertise to run a large company. Large capital-intensive state enterprises should be privatized when a reasonable sales value of the firms can be formulated - mainly hand in hand with the rise of market practices following restructuring, the participation of foreign capital, and, in some cases, liquidation. Otherwise, randomly fixed prices would open the gates to corruption and irregularities. Łaski concluded that no private investment of major size could compensate for state investment, and the dramatic increase in long-term unemployment could undermine the living conditions of the 
broad masses and the political support for reforms. The state should accept its responsibilities to avoid mass unemployment and keep a certain scope of investment in state enterprises (i) to protect the capital stock and prepare it for privatization, and (ii) to help modernize the industries with the best prospects to survive the transition. Like some other authors of this time who favoured a gradual transition, Łaski described this process as necessarily transitional or 'forced' market socialism during the entire transition process (Łaski 1992d: 64-66). The reader should notice that this market socialism is completely different from the traditional concept where the state activates the law of value' or a market mechanism as completion of central planning. 'Market socialism' is closer to a conclusion from his critical analysis in his joint book with Brus (Brus/Łaski 1989: 149):

On balance, although the pure logic of the fully fledged market mechanism seems to indicate the non-state (private or cooperative) as the more natural constituent of the enterprise sector of MS [market socialism] the case for state enterprise should not be regarded as inevitably lost.... Thus, a mixed economy where various forms of state enterprise would gradually be made to compete on an equal footing with private firms and cooperatives seems the only realistic prospect for MS in the foreseeable future.

This vision of feasible market socialism is fairly close to a social democratic economic model, which Mario Nuti has described in more detail in a recent paper and which could be suitable to deal with the challenges and problems raised by globalization and neoliberal policies (Nuti 2018).

\section{FINAL COMMENTS}

Wherever it is applied to solve severe economic and social crises, the neoliberal agenda has produced an economic and social disaster for the broad population with far-reaching consequences. The 'lost decade' in Latin America found its equivalent in the saying about a 'lost generation' in the former socialist countries. Another example is the neoliberal constitution of the European monetary union, which forced the Southern member states into severe austerity programmes with long-lasting economic, social and political damages. Actually, neoliberal politicians played with the fate of millions of people - and they needed favourable external conditions. The neoliberal aversion to an economically active state is still present in most textbooks, as well as policy-consulting and policy-making. In this respect the constitution of the European monetary union provides a powerful example, though the failures during transition and in the euro debt crisis has reinforced some doubts. Łaski contributed to the contemporary critique of neoliberal positions. He contributed to the recent revival of the theories of Kalecki, the other 'leader of the Keynesian revolution' (Toporowski 2018: 79), and he summarized his own contributions in an interview in 2006 (Easki 2006: 8) with the following words:

A number of my former Linz students and collaborators, presently occupying important positions in higher education and government administration, defy mainstream economy and act in the direction of a more efficient and egalitarian society. I feel I have contributed to this as I have also some modest share in the international reputation WIIW has gained over the years. In this way I may have paid back my debt to my host country and contributed at the same time to preserve the intellectual heritage of Kalecki.

These are not minor achievements. 


\section{REFERENCES}

Bhaduri, A., Łaski K. (1997): Lessons to be drawn from main mistakes in the transition strategy, in: Zeccini, S. (ed.), Lessons from the Economic Transition: Central and Eastern Europe in the 1990s, Dordrecht, Boston and London: Kluwer, 103-123.

Bhaduri, A., Łaski, K., Riese, M. (2003): Making sense of the aggregate demand-supply model, in: Investigacion Economica, 63(243), 51-71.

Brus, W. (1993): The bane of reforming the socialist economic system, in: BNL Quarterly Review, 187, 364-405.

Brus, W., Łaski, K. (1965): The Law of Value and the problem of allocation in socialism, in: Zhow, Y. (ed.), On Political Economy and Econometrics: Essays in Honour of Oskar Lange, Oxford: Pergamon Press, 45-61.

Brus, W., Łaski, K. (1989): From Marx to the Market: Socialism in Search of an Economic System, Oxford: Oxford University Press.

Brus, W., Łaski, K. (1990): Von Marx zum Markt, Marburg: Metropolis.

Gomułka, S. (1991): The causes of recession following stabilization, in: Comparative Economic Studies, XXXIII(2), 71-90.

Gomulka, S., Kowalik, T. (eds) (2011): Transformacja Polska-dokumenty i analizy 1990, Warszawa: Wydawnictwo Naukow Scholar.

IMF (1993): IMF Survey, 22(9), 3 May.

Kalecki, M. (1956 [1992]): Workers' councils and central planning, in: Osiatyński, J. (ed.): Collected Works of Michal Kalecki, vol. III, Oxford: Clarendon Press, 56-69.

Kalecki, M. (1971): 'Cost-determined' and 'demand determined' prices, in: Selected Essays on the Dynamics of the Capitalist Economy, 1933-1970, Cambridge, UK: Cambridge University Press, 43-61.

Kornai, J. (1997): Adjustment without recession: a case study of Hungarian stabilization, in: Zeccini, S. (ed.), Lessons from the Economic Transition: Central and Eastern Europe in the 1990s, Dordrecht, Boston and London: Kluwer, 123-153.

Łaski, K. (1990 [2011]): Notatka dla p. Min. J. Osiatynskiego o niezpieczenstwach zwiazanych z planem stabilizacji gospodarki narodowej, in: Gomulka, S., Kowalik T. (eds), Transformacja Polska - dokumenty $i$ analizy 1990, Warszawa: Wydawnictwo Naukowe Scholar, 142-151.

Łaski, K. (1992a): Transition from command to market economies in Central and Eastern Europe: first experiences and questions, in: Richter, S. (ed.), The Transition from Command to Market Economies in East-Central Europe, WIIW Yearbook IV, Boulder, CO: Westview, 33-55.

Łaski, K. (1992b): Comments on Leipold, in: Saunders, C.T. (ed.), Economics and Politics of Transition, Basingstoke and London: Macmillan, 94-97.

Łaski, K. (1992c): Der aktuelle Stand der Diskussion über die Transformationsprobleme, in: Europäische Rundschau: Vierteljahreszeitschrift für Politik, Wirtschaft und Zeitgeschichte, 20(4), 35-44.

Łaski, K. (1992d): Concepts of transition in socialist economies, in: Saunders, C.T. (ed.), Economics and Politics of Transition, Basingstoke and London: Macmillan, 63-73.

Łaski, K. (1993): Fiscal policy and effective demand during transformation, Wiener Institut für Internationale Wirtschaftsvergleiche WIIW Forschungsberichte, No 189.

Łaski, K. (1995): Fiscal policy and effective demand during transformation, in: Schriften des Vereins für Socialpolitik. Neue Folge Band 236, Berlin: Duncker \& Humblot, 61-81.

Łaski, K. (1997): Macroeconomic problems of trade liberalization and EU Eastern enlargement, Wiener Institut für Internationale Wirtschaftsvergleiche WIIW Forschungsberichte, No 241.

Łaski, K. (2006): Kalecki's place in my career as economist, in: European Association for Evolutionary Political Economy, EAEPE Newsletter 36, 2-5, URL: http://eaepe.org/content/documents/ NewsletterArchive/EAEPE_NewsletterNo36_Jul2006.pdf (accessed 16 November 2018).

Łaski, K. (2012): Life is stronger than dogma, in: Interventions. 17 Interviews with Unconventional Economists (2007-2012), Marburg: Metropolis, 125-133.

Łaski, K. (2015): Gospodarka kapitalistiyczna bez bezrobocia (A Capitalist Economy Without Unemployment), Warszawa: Polskie Towarzystwo Ekonomiczne; Wyklady z makroekonomii. 
Mayrhofer, P. (2015): Rolle der Oesterreichischen Nationalbank bei West-Ost-Transfers im Rahmen des Wiener Instituts für Wirtschaftsvergleiche 1972/73-1991, URL: https://www.oenb.at/UeberUns/unternehmensgeschichte/200-jahr-jubilaeum/publikationen.html (accessed 20 July 2018).

Nuti, M. (2018): The rise, fall and future of socialism, URL: https://www.socialeurope.eu/the-risefall-and-future-of-socialism-1 (accessed 17 November 2018).

Osiatyński, J. (1987): Kalecki's School in the theory of growth of a socialist economy, in: Fink, G., Pöll, G., Riese, M. (eds), Economic Theory, Political Power and Social Justice: Festschrift Kazimierz Laski, Wien and New York: Springer, 111-137.

Toporowski, J. (2018): Michat Kalecki: An Intellectual Biography, Vol. 2, Basingstoke, UK: Palgrave Macmillan.

Weber, I.M. (2017): China's Escape from the Big Bang: The 1980s Price Reform Debate in Historical Perspective, PhD Dissertation, Center of Development Studies, Department of Politics and International Studies, University of Cambridge. Forthcoming as Reassessing China's Reform Debate (1978-1988): Market Creation and Price Regulation, Abingdon, UK and New York: Routledge. 